\title{
ABCA1 is associated with the development of acquired chemotherapy resistance and predicts poor ovarian cancer outcome
}

\author{
Wanqi Wang ${ }^{1}$, Noor A Lokman¹, Tannith M Noye ${ }^{1}$, Anne M Macpherson ${ }^{1}$, Martin K Oehler ${ }^{1,2}$, Carmela \\ Ricciardelli ${ }^{1}$ \\ 'Adelaide Medical School, Robinson Research Institute, University of Adelaide, Adelaide, SA 5000, Australia. \\ 2Department of Gynaecological Oncology, Royal Adelaide Hospital, Adelaide, SA 5000, Australia.
}

Correspondence to: Dr. Carmela Ricciardelli, Adelaide Medical School, University of Adelaide, Adelaide Health and Medical Sciences Building, North Terrace, Adelaide 5000, Australia. E-mail: carmela.ricciardelli@adelaide.edu.au

How to cite this article: Wang W, Lokman NA, Noye TM, Macpherson AM, Oehler MK, Ricciardelli C. ABCA1 is associated with the development of acquired chemotherapy resistance and predicts poor ovarian cancer outcome. Cancer Drug Resist 2021;4:485-502. http:dx.doi.org/10.20517/cdr.2020.107

Received: 26 Nov 2020 First Decision: 13 Jan 2021 Revised: 26 Jan 2021 Accepted: 4 Feb 2021 Available online: 19 Jun 2021

Academic Editor: Godefridus J. Peters Copy Editor: Yue-Yue Zhang Production Editor: Xi-Jun Chen

\begin{abstract}
Aim: This study investigated the ATP binding cassette $(A B C)$ transporter ( $A B C A 1, A B C B 1, A B C B 3, A B C C 2$ and $A B C G 2$ ) expression in high grade serous ovarian cancer (HGSOC) tissues, cell lines and primary cells to determine their potential relationship with acquired chemotherapy resistance and patient outcome.
\end{abstract}

Methods: $A B C$ transporter mRNA and protein expression ( $A B C A 1, A B C B 1, A B C B 3, A B C C 2$ and $A B C G 2$ ) was assessed in publicly available datasets and in a tissue microarray (TMA) cohort of HGSOC at diagnosis, respectively. $A B C$ transporter mRNA expression was also assessed in chemosensitive ovarian cancer cell lines (OVCAR-5 and $\mathrm{CaOV} 3$ ) versus matching cell lines with acquired carboplatin resistance and in primary HGSOC cells from patients with chemosensitive disease at diagnosis $(n=10)$ as well as patients with acquired chemotherapy resistance at relapse $(n=6)$. The effects of the ABCA1 inhibitor apabetalone in carboplatinsensitive and -resistant cell lines were also investigated.

Results: High $A B C A 1$ mRNA and protein expression was found to be significantly associated with poor patient outcome. ABCA1 mRNA and protein levels were significantly increased in ovarian cancer cell lines (OVCAR-5 CBPR and $\mathrm{CaOV} 3 \mathrm{CBPR}$ ) with acquired carboplatin resistance. $A B C A 1$ mRNA was significantly increased in primary HGSOC cells obtained from patients with acquired chemotherapy resistance. Apabetalone treatment reduced

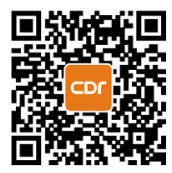


ABCA1 protein expression and increased the sensitivity of both parental and carboplatin-resistant ovarian cancer cells to carboplatin.

Conclusion: These results suggest that inhibiting $A B C A 1$ transporter may be useful in overcoming acquired chemotherapy resistance and improving outcome for patients with HGSOC.

Keywords: $\mathrm{HGSOC}$, chemotherapy resistance, $A B C$ transporter, $A B C A 1, A B C B 1, T A P 2, A B C B 3, A B C C 2, A B C G 2$, apabetalone

\section{INTRODUCTION}

Ovarian cancer is the most lethal gynecological malignancy in the developed world ${ }^{[1]}$. Epithelial ovarian cancer, which includes serous, clear cell, mucinous and endometrioid subtypes, constitutes $90 \%$ of ovarian cancers $^{[2]}$. Up to $70 \%$ of epithelial ovarian cancers are high grade serous ovarian cancers (HGSOC), which are the most common and deadliest ovarian cancer subtype ${ }^{[2]}$. HGSOC is usually diagnosed at an advanced stage and current treatment strategies include a combination of radical debulking surgery and chemotherapy (carboplatin + paclitaxel). Although the initial responses to chemotherapy treatment are high, up to $60 \%$ of ovarian cancer patients relapse within six months and $75 \%$ of patients ultimately become chemoresistant, which is the main factor contributing to ovarian cancer death ${ }^{[2]}$. The development of more effective therapies for chemotherapy disease is urgently required for improving the survival rate of ovarian cancer patients.

The basis for the chemoresistance is multifactorial involving both tumor and drug related factors ${ }^{[3-6]}$. A potential mechanism involves the increased expression of ATP-binding cassette (ABC) transporter membrane proteins, which can decrease levels of chemotherapy drugs within cells ${ }^{[7]}$. Although studies including ovarian cancer subtypes have suggested that $\mathrm{ABC}$ transporters are associated with reduced survival and chemotherapy resistance, the findings have been very inconsistent ${ }^{[7,8]}$.

$\mathrm{ABC}$ transporters constitute a ubiquitous superfamily of integral membrane proteins that are responsible for the ATP powered translocation of substrates across membranes. There are seven subfamilies of ABC transporters (ABCA-ABCG) including $49 \mathrm{ABC}$ transporters in humans ${ }^{[7]}$. Most $\mathrm{ABC}$ transporters are inward opening and couple the hydrolysis of ATP to export molecules in a unidirectional path across the phospholipid bilayer of cellular membranes, against a chemical gradient ${ }^{[7]}$. Four subfamilies (ABCA ABCB, $A B C C$ and $A B C G)$ have been shown to be associated with drug resistance in ovarian cancer ${ }^{[7]}$.

This study investigated the relationship of the five $\mathrm{ABC}$ transporters $\mathrm{ABCA1}, \mathrm{ABCB} 1, \mathrm{ABCB} 3$ (also known as TAP2), ABCC2 and ABCG2 with ovarian cancer chemoresistance and outcome. The rationale for selecting these $A B C$ transporters were: (1) $A B C A 1$ has been widely studied as a cholesterol transporter, and platinum drugs commonly used for ovarian cancer are drug substrates for $\mathrm{ABCA}_{1}{ }^{\left[{ }^{[}\right]}$. Increased ABCA1 mRNA/protein expression was found to be associated with poor clinical outcome in bowel ${ }^{[10]}$ and ovarian cancer ${ }^{[11]}$. It was also associated with lymph node metastasis in breast cancer ${ }^{[12]}$; (2) Paclitaxel that is commonly used for ovarian cancer patients is a drug substrate for $\mathrm{ABCB} 1$. Studies have shown that high $\mathrm{ABCB} 1 \mathrm{mRNA}$ /protein expression was associated with poor clinical outcome and chemoresistance in many cancers, including ovarian cancer ${ }^{[13-16]}$; However, some studies found no or the opposite relationship ${ }^{[17,18]}$; (3) $\mathrm{ABCB} 3$ was chosen as it is in the same subfamily as $\mathrm{ABCB} 1$ and closest in structure to $\mathrm{ABCB} 1$ but has not been widely studied in ovarian cancer ${ }^{[7]}$. Limited studies to date have shown that high $\mathrm{ABCB} 3$ mRNA/protein expression was associated with chemoresistance ${ }^{[7,19]}$ but better clinical outcome in ovarian cancer $^{[20,21]}$; (4) Several studies have found ABCC2 overexpression in ovarian cancer patients with poor 
clinical outcome and chemotherapy response ${ }^{[22,23]}$, yet contrary studies exist ${ }^{[24,25]}$; and (5) ABCG2 is known as a stem cell marker that is associated with chemoresistance ${ }^{[2,26]}$ but has been poorly studied in ovarian cancer.

\section{METHODS}

\section{Analysis of public ovarian cancer microarray databases}

Progression-free survival (PFS), post-progression survival (PPS) and overall survival (OS) Kaplan-Meir analyses were performed using Affymetrix mRNA microarray expression data from the Kaplan-Meier plotter (http://kmplot.com/analysis/index.php?p=service\&cancer $=$ ovar $)^{[28]}$. Gene probes included $A B C A 1$ (203504_s_at, 203505_at and 216066_at), ABCB1 (209993_at and 209994_s_at), ABCB3/TAP2 (204769_s_at, 204770_at, 225973_at and 208428_at), ABCC2 (206155_at) and ABCG2 (209735_at). The online plotter tool was used to select the best cut-off to split the patients into two groups (high and low expression) for each analysis. For transporters with more than one mRNA probe, the mean expression was calculated by the online plotter tool. The analyses were performed on the 2017 version of 13 public microarray databases for all ovarian cancer patients (serous and endometroid) or HGSOC (serous grade 2 and 3) patients ${ }^{[28]}$.

\section{Patient tissue cohort}

Tissue microarrays (TMA) (1 mm diameter tissue cores) in triplicate were obtained from a uniform cohort of HGSOC $(n=147)$ diagnosed between 1988 and 2013. Supplement Table 1 summarizes the clinicopathological characteristics of the TMA patient cohort. The research was conducted with patient consent and approval by the Royal Adelaide Hospital Human Ethics Committee (RAH protocols \#060903 and \#140201). Up to $81.5 \%$ of the patients received platinum chemotherapy as first line treatment.

\section{Immunohistochemistry}

Immunohistochemistry was performed on TMA and tissue sections as described previously ${ }^{[29]}$. Archived formalin fixed paraffin embedded tissue sections $(5 \mu \mathrm{m})$ were incubated at $60{ }^{\circ} \mathrm{C}(1.5 \mathrm{~h})$, dewaxed and rehydrated using xylene and decreasing concentrations of ethanol. Tissue sections were washed with PBS and blocked for endogenous peroxidase activity with $0.3 \%$ hydrogen peroxide in PBS (5 min). Sections then underwent steam microwave antigen retrieval in $10 \mathrm{mM}$ citric acid buffer, $\mathrm{pH} 6$ at $100{ }^{\circ} \mathrm{C}(10 \mathrm{~min})$ (Sixth sense, Whirlpool, Australia). TMAs were blocked with $5 \%$ goat serum (30 min) and incubated overnight at $4{ }^{\circ} \mathrm{C}$ with primary antibodies: ABCA1 (1/200, polyclonal, NB400-105, Novus Bio $)^{[30,31]}, \mathrm{ABCB} 1(1 / 1200$, clone F4, P7965, Sigma Aldrich) $)^{[32]}, \mathrm{ABCB}_{3}$ (1/750, TAP2, Ab130414, Abcam Cambridge UK $)^{[7]}$, ABCC2 (1/50, clone M2I-4, Ab3372, Abcam) $)^{[33]}$ and ABCG2 (1/100, clone BXP-21, Abcam) ${ }^{[34]}$. The next day, sections were incubated sequentially with secondary antibodies: biotinylated goat anti-rabbit (1/400, Dako, Australia) for $\mathrm{ABCA} 1$ and $\mathrm{ABCB} 3$ or biotinylated goat anti-mouse (1/400, Dako, Australia) for $\mathrm{ABCB} 1$, ABCC2 and ABCG2, followed by streptavidin-horseradish peroxidase (1/500, Dako, Australia) at room temperature $(1 \mathrm{~h})$. Peroxidase activity was detected using diaminobenzidine (DAB) and $\mathrm{H}_{2} \mathrm{O}_{2}$ (SigmaAldrich). Sections were counterstained with hematoxylin (Sigma-Aldrich), dehydrated with $70 \%$ and 100\% ethanol and xylene, and then mounted in Pertex (Medite Medizintechnik, Germany). Tissues without primary antibody or mouse/rabbit immunoglobulins were included as negative controls. Previous studies have found $\mathrm{ABCA1} 1^{[35]}, \mathrm{ABCB} 1^{[36,37]}$ and $\mathrm{ABCB} 3^{[38]}$ expression in colon tissue and $\mathrm{ABCC} 2^{[37,39]}$ and $\mathrm{ABCG} 2^{[37]}$ expression in liver tissue, and these were used as positive controls for the immunohistochemistry.

\section{Immunohistochemistry assessment}

Tissue sections were scanned by NanoZoomer Digital Pathology System (Hamamatsu Photonics, SZK, Japan) and viewed by NDP view imaging software (NDP scan software v2.3, Hamamatsu Photonics). Intensity levels of $\mathrm{ABC}$ transporters in serous ovarian cancer cells and the percentage of positively stained cells were assessed using a manual scoring method by three independent researchers as described previously ${ }^{[40]}$. Staining intensity was graded as 0 : negative; 1 : weak; 2: moderate; or 3: strong. The percentage 
of positively stained tumor cells was scored as 0 : none; $1: \leq 10 \%$ positive cells; $2: 11 \%-50 \%$ positive cells; 3 : $51 \%-80 \%$ positive cells; or $4:>80 \%$ positive cells. Immunoreactive score (IR) was calculated by multiplying the percentage of positive cells with the intensity of staining ${ }^{[40]}$.

\section{Cell culture}

Human serous ovarian cancer cell line CaOV3 was purchased from American Type Culture Collection. OVCAR-5 cells were obtained from Dr Thomas Hamilton (Fox Chase Cancer Center, PA, USA). Cell lines were grown in RPMI-1640 media (Sigma Aldrich, catalog number R8758, OVCAR-5) or DMEM media (Gibco, Life Technologies, catalog number 10567-022, CaOV3), cultured at $37{ }^{\circ} \mathrm{C}$ in a humidified environment of $5 \% \mathrm{CO}_{2}$, with $10 \%$ fetal bovine serum (FBS, Scientifix, catalog number AFBS500), antibiotics penicillin-streptomycin (1:100, Sigma-Aldrich, catalog number P4458) and antibiotic antimycotic solution (1:500, Sigma-Aldrich, catalog number A5955). OVCAR-5 and CaOV3 cells were made resistant to carboplatin (OVCAR-5 CBPR; CaOV3 CBPR) following treatment with eight cycles of carboplatin (CBP, $50 \mu \mathrm{M}$, Hospira Australia Pty, Ltd) as previously described ${ }^{[29]}$. The OVCAR-5 and CaOV 3 carboplatin resistant $(\mathrm{CBPR})$ cells exhibit a carboplatin $\mathrm{IC}_{50}$ that was nearly three-fold higher than that of the parental OVCAR-5 or CaOV3 cells [Supplement Figure 1].

Primary serous ovarian cancer cells were derived from ascites collected from patients with chemosensitive disease at diagnosis $(n=9)$ or following the development of acquired chemoresistant disease $(n=6)$ as described previously ${ }^{[4]}$. Ascites was obtained with patient consent and approval by the Royal Adelaide Hospital (RAH protocol number 140201) and Central Adelaide Local Health Network Human Ethics Committees (CALHN \#R20181215). Pathological and clinical characteristics of the patients whose ascites was used to isolate the primary cells are summarized in Supplement Table 2. All primary cells were grown in Advanced RPMI-1640 medium (Life Technologies catalog number 12633-020) supplemented with $2 \mathrm{mM}$ GlutaMAX $^{\mathrm{mm}}$ (Life Technologies, catalog number 35050061), 10\% FBS and antibiotics between passages 1 and 4 .

\section{Quantitative real-time PCR (qRT-PCR)}

OVCAR-5, OVCAR-5 CBPR, CaOV-3 and CaOV-3 CBPR cell lines as well as primary ovarian cancer cells were plated at 5000 cells/well in 96-well plates and cultured for 72-96 h until confluent. Total RNA was isolated and reverse-transcribed using the TaqMan ${ }^{\bullet}$ Gene expression Cells-to CT kit (Applied Biosystems, Thermo Fisher Scientific, Waltham, MA, USA), as per the manufacturer's instructions as previously described $^{[41]}$. Briefly, lysis solution with DNAse was added to each well with incubation at room temperature $(5 \mathrm{~min})$. Then, stop solution was added and mixed to each well. Ten microliters of lysate were added to a $40 \mu \mathrm{L}$ reverse transcription master mix for $1 \mathrm{~h}$. Resultant cDNA was stored for qRT-PCR analysis as $50 \mu \mathrm{L}$ aliquots at $-20^{\circ} \mathrm{C}$. Quantstudio $12 \mathrm{~K}$ Flex Real-Time PCR System (Applied Biosystems) was used for qRT-PCR reactions that were performed on triplicate samples using TaqMan ${ }^{\circledR}$ primer sets for $A B C A 1$ (Hs01059137), ABCB1 (Hs00184500), ABCB3 (Hs00241060), ABCC2 (Hs00166123) and ABCG2 (Hs01053790). PCR reactions were made up to $10 \mu \mathrm{L}$ containing: TaqMan ${ }^{\oplus}$ Gene Expression Master Mix (2x), primers for the gene of interest, nuclease-free water and $2 \mu \mathrm{L}$ sample cDNA. PCR cycling conditions were: $50{ }^{\circ} \mathrm{C}(2 \mathrm{~min}), 95{ }^{\circ} \mathrm{C}(10 \mathrm{~min})$ followed by 40 cycles of $95{ }^{\circ} \mathrm{C}(15 \mathrm{~s})$ and $60{ }^{\circ} \mathrm{C}(1 \mathrm{~min})$. qRT-PCR negative controls included samples without RNA or cDNA. CT values were normalized to the housekeeping gene $\beta$-actin (Human ACTB 4333762, Applied Biosystems) and calibrator using the $2^{-\Delta \Delta C T}$ method.

\section{Immunocytochemistry}

Ovarian cancer cells (OVCAR-5, OVCAR-5 CBPR, CaOV3 and CaOV3 CBPR) were plated at $1 \times 10^{5}$ cells/well in eight-well tissue culture chamber slides (Nunclon ${ }^{\mathrm{mm}}$ Lab-Tek II Chamber slide, ThermoFisher Scientific) in growth media (500 $\mu \mathrm{L} 10 \%$ FBS RPMI). Cells were fixed with ice-cold 100\% methanol ( 3 min) and ice-cold 100\% acetone (1 min), washed with PBS, blocked with $5 \%$ goat serum and incubated overnight 
with ABCA1 rabbit polyclonal antibody (1/100, NB400-105, Novus Biological). Protein expression was visualized with goat anti-rabbit Alexa Fluor 488 for $1 \mathrm{~h}$ at room temperature (1/200, catalog number A11034, Molecular Probes, Life Technologies), and slides were mounted with Prolong Gold Antifade Mountant with DAPI (catalog number P36941, Molecular Probes, Life Technologies). Cells were viewed with an epifluorescence microscope (BX50, Olympus Australia) and imaged using a 40x objective and a Spot RT digital camera (Diagnostic Instruments, Sterling Heights, MI). Negative controls included rabbit immunoglobulin or no primary antibody.

\section{Cell survival assay}

OVCAR-5 (5000 cells/well) and CaOV3 (7500 cells/well) cells were plated in 96-well plates in respective growth media. After $24 \mathrm{~h}$, cells were treated with control media (DMSO, 0.06\%), apabetalone (1-80 $\mu \mathrm{M}$, RVX-208, catalog number S7295, SelleckChem, Houston, TX, USA), carboplatin (5-200 $\mu$ M, Hospira, Australia) or apabetalone $(80 \mu \mathrm{M})+$ carboplatin $(5-200 \mu \mathrm{M})$ for $72 \mathrm{~h}$. Cell survival was assessed by MTT assay as per the manufacturer's instructions (Sigma Aldrich) ${ }^{[42]}$. Curve fitting using log(inhibitor) vs. normalized response - variable slope (Graph Pad Prism, Prism ${ }^{\circledR}$, version 8.0.0, CA, USA) was used to calculate the carboplatin $\mathrm{IC}_{50}$ in the absence and presence of apabetalone. Combination index was determined according to the Chou-Talalay method ${ }^{[43]}$ using CompuSyn software (ComboSyn, Inc. New Jersey, USA). Drug interactions were considered synergistic, additive or antagonistic with combination index values of $<1,1$ and $>1$, respectively.

\section{Western blotting}

Protein extracts from ovarian cancer cell lines following 48-72 h treatment with apabetalone (20-80 $\mu \mathrm{M}$ prepared in RIPA buffer and electrophoresed on 4\%-20\% TGX gels (Bio-Rad Laboratories, Hercules, US) and transferred onto polyvinylidene difluoride membranes (GE Healthcare, Little Chalfont, England) ${ }^{[29,44]}$. The membranes were subsequently incubated with rabbit polyclonal antibody ABCA1 (1/1000, NB400-105, Novus Biological) for $2 \mathrm{~h}$ at room temperature and then peroxidase-conjugated anti-rabbit IgG (1/4000, Millipore, Australia) for $1 \mathrm{~h}$ at room temperature. Chemiluminescence (ECL Hyperfilm, GE Healthcare) was used to visualize protein expression. Membranes were scanned using ChemiDoc ${ }^{\mathrm{m}}$ MP Imaging System (Bio-Rad Laboratories, Inc) and analyzed using Image Lab ${ }^{\mathrm{m}}$ software (Version 6.0.1 build 34, Bio-Rad Laboratories, Inc). $\beta$-actin anti-rabbit antibody (1/5000, Abcam catalog number Ab8227) was used as a loading control.

\section{Statistical analyses}

$A B C A 1, A B C B 1, A B C B 3, A B C C 2$ and $A B C G 2$ mRNA expression in public datasets was analyzed by Kaplan-Meier online plotter and used to calculate the hazard ratio, 95\%CI, log-rank $P$ value and KaplanMeier survival curves ${ }^{[28]}$. In Kaplan-Meier online plotter, PPS is calculated from time of first progression to time of death, PFS survival is calculated from date of diagnosis to first progression and OS is calculated from date of diagnosis to date of death. Kaplan-Meier analyses were performed to assess the relationship of $\mathrm{ABCA} 1, \mathrm{ABCB} 1, \mathrm{ABCB} 3, \mathrm{ABCC} 2$ and $\mathrm{ABCG} 2$ protein expression in the HGSOC TMA cohort with PFS and OS (SPSS software, version 21.0, SPSS Inc., Chicago, IL, USA). Median IR scores or cut-off points either side of the median were used for Kaplan-Meir survival analysis. Relapse or death due to ovarian cancer was used as the endpoint. The following statistical analyses were all performed using Graph Pad Prism (Prism ${ }^{\circ}$ version 8.0.0): unpaired Student's $t$-test for comparing mRNA expression between parental and carboplatin resistant cell lines, one-way ANOVA (Tukey's multiple comparisons test) for assessing response to different concentrations of apabetalone and the Mann-Whitney $U$ test for analyzing mRNA expression in chemosensitive and -resistant primary HGSOC cells. Statistical significance was accepted at $P<0.05$. 
Table 1. Relationship between ABC transporter mRNA expression and ovarian cancer outcome using Kaplan-Meir plotter

\begin{tabular}{|c|c|c|c|c|c|c|c|c|c|}
\hline \multirow{2}{*}{$\begin{array}{c}\mathrm{ABC} \\
\text { transporter }\end{array}$} & \multicolumn{3}{|c|}{ Progression-free survival } & \multicolumn{3}{|c|}{ Post-progression-free survival } & \multicolumn{3}{|c|}{ Overall survival } \\
\hline & HR & $95 \% \mathrm{Cl}$ & $P$ value & HR & $95 \% \mathrm{Cl}$ & $\begin{array}{c}P \\
\text { value }\end{array}$ & HR & $95 \% \mathrm{Cl}$ & $P$ value \\
\hline \multicolumn{10}{|c|}{ (A) All ovarian cancers } \\
\hline ABCA1 & $1.20(n=1435)$ & $(1.05-1.38)$ & 0.009 & $1.22(n=782)$ & $(1.02-1.46)$ & 0.028 & $1.08(n=1656)$ & $(0.94-1.24)$ & 0.27 \\
\hline ABCB1 & $1.12(n=1435)$ & $(0.98-1.28)$ & 0.088 & $0.86(n=782)$ & $(0.7-1.05)$ & 0.13 & $1.07(n=1656)$ & $(0.94-1.22)$ & 0.31 \\
\hline АВСВ3 & $1.67(n=1435)$ & $(1.36-2.05)$ & $<0.0001$ & $0.72(n=782)$ & $(0.56-0.92)$ & 0.008 & $0.85(n=1656)$ & $(0.68-1.07)$ & 0.17 \\
\hline ABCC2 & $0.85(n=1435)$ & $(0.75-0.96)$ & 0.011 & $1.23(n=782)$ & $(1.02-1.48)$ & 0.029 & $1.13(n=1656)$ & $(0.99-1.30)$ & 0.075 \\
\hline ABCG2 & $0.87(n=1435)$ & $(0.77-0.99)$ & 0.032 & $0.85(n=782)$ & $(0.72-1.01)$ & 0.059 & $0.91(n=1656)$ & $(0.80-1.04)$ & 0.15 \\
\hline \multicolumn{10}{|c|}{ (B) High grade serous ovarian cancers } \\
\hline ABCA1 & $1.20(n=1029)$ & $(1.02-1.4)$ & 0.026 & $1.28(n=698)$ & $(1.06-1.55)$ & 0.009 & $1.11(n=1144)$ & $(0.94-1.31)$ & 0.21 \\
\hline ABCB1 & $1.16(n=1029)$ & $(1.00-1.35)$ & 0.056 & $1.08(n=698)$ & $(0.91-1.29)$ & 0.39 & $0.89(n=1144)$ & $(0.76-1.05)$ & 0.17 \\
\hline ABCB3 & $0.73(n=1029)$ & $(0.57-0.94)$ & 0.014 & $0.74(n=698)$ & $(0.56-0.97)$ & 0.028 & $0.72(n=1144)$ & $(0.57-0.92)$ & 0.0076 \\
\hline ABCC2 & $1.17(n=1029)$ & $(0.98-1.38)$ & 0.074 & $1.24(n=698)$ & $(1.02-1.52)$ & 0.032 & $1.15(n=1144)$ & $(0.96-1.38)$ & 0.12 \\
\hline ABCG2 & $1.1(n=1029)$ & $(0.93-1.29)$ & 0.28 & $0.85(n=698)$ & $(0.71-1.01)$ & 0.07 & $0.91(n=1144)$ & $(0.78-1.06)$ & 0.22 \\
\hline
\end{tabular}

Significant results $(P<0.05)$ are highlighted in bold.

\section{RESULTS}

Relationship between ABC transporter mRNA expression with outcome in all ovarian cancer subtypes and HGSOC

By analyzing publicly available microarray data using the Kaplan-Meir online plotter ${ }^{[28]}$, high $A B C A 1$ and $A B C B 3$ mRNA expressions were significantly associated with reduced PFS in all ovarian cancer subtypes [Table 1A]. High ABCC2 and ABCG2 expressions were associated with increased PFS in all ovarian cancer subtypes [Table $1 \mathrm{~A}$ ]. High $A B C A 1$ expression was significantly associated with reduced PFS when only HGSOC was included in the analysis [Table $1 \mathrm{~B}$ ]. High ABCA1 and ABCC2 mRNA were significantly associated with reduced PPS in all ovarian cancer subtypes [Table 1A] and HGSOC [Table 1B]. High $A B C B 3$ mRNA expression was significantly associated with increased PPS in all ovarian cancer subtypes [Table 1A] and HGSOC [Table 1B]. Only high $A B C B 3$ expression was significantly associated with increased OS in patients with HGSOC [Table $1 \mathrm{~B}]$.

\section{High $A B C A 1$ and $A B C B 1$ transporter protein expression are associated with reduced overall survival in HGSOC patients}

Examples of high and low ABC transporter protein expression in HGSOC patient tissues are shown in Figure 1. Strong staining was observed in positive control in human colon tissues for $\mathrm{ABCA}$, $\mathrm{ABCB} 1$ and $\mathrm{ABCB} 3$ and mouse liver tissues for ABCC2 and ABCG2 [Supplement Figure 2]. Using Kaplan-Meier survival analyses in HGSOC cohort, no significant findings were observed between $\mathrm{ABCA} 1, \mathrm{ABCB} 1$, $\mathrm{ABCB} 3$ or $\mathrm{ABCC} 2$ protein expression and PFS [Figure 2A-D]. Patients with high ABCG2 IR score (IR $\geq$ 10) had reduced PFS compared to patients with lower IR score $[\mathrm{IR} \leq 9, P=0.051$, Figure $2 \mathrm{E}]$. Patients with high ABCA1 (IR score $\geq 9$ ) [Figure $3 \mathrm{~A}, P=0.032$ ] or high $\mathrm{ABCB} 1$ (IR score $\geq 3$ ) [Figure $3 \mathrm{~B}, P=0.004$ ] had significantly reduced OS. However, no significant relationship was observed between OS and the expression of the other $\mathrm{ABC}$ transporters [Figure $3 \mathrm{C}-\mathrm{E}$ ]. Cox regression analysis confirmed that increased $\mathrm{ABCA} 1$ and $\mathrm{ABCB} 1$ expression is associated with reduced OS [Table 2A]. Both ABCA1 and ABCB1 expression remained independent predictors of OS when combined in a multivariate analysis [Table $2 \mathrm{~B}$ ]. No relationship was observed between expression of the ABC transporters and PFS using Cox regression analysis (data not shown). 


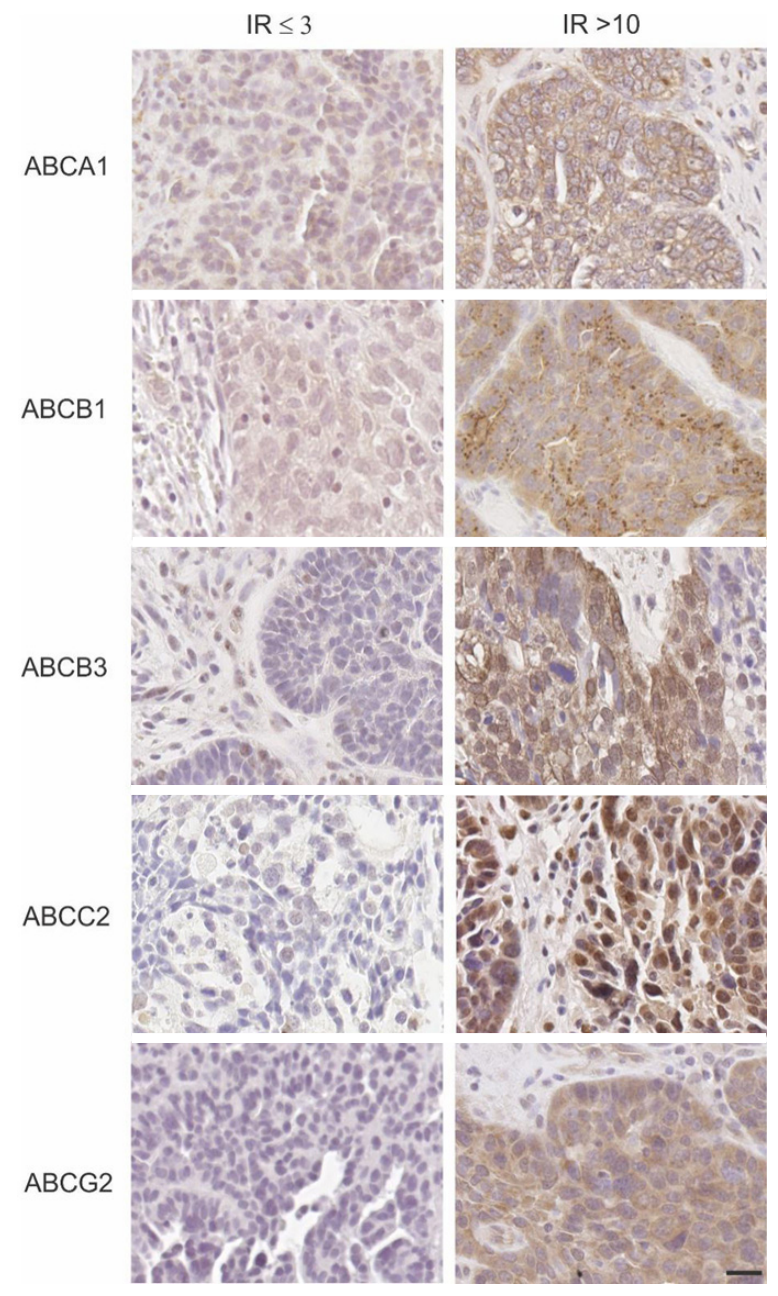

Figure 1. $A B C$ transporter protein expression in high grade serous ovarian cancer patient tissue cohorts. Examples are shown for each transporter [low expression with immunoreactive score $(I R) \leq 3$ (left column); high expression with IR $>10$ (right column)]. All images are at the same magnification. Scale bar $=20 \mu \mathrm{m}$. IR:Immunoreactive score.

\section{ABCA1 expression is increased in serous ovarian cancer cells with acquired chemotherapy resistance}

ABCA1 mRNA expression was significantly increased in OVCAR-5 CBPR $(\sim 2$-fold, $P=0.017)$ and CaOV3 CBPR ( $~ 3$-fold, $P=0.007$ ) ovarian cancer cell lines, compared to parental OVCAR-5 and CaOV3 cell lines [Figure 4A]. ABCA1 mRNA levels were significantly increased in primary HGSOC cells obtained from patients with acquired chemotherapy resistance at relapse compared to patients with chemosensitive disease at diagnosis [Figure $4 \mathrm{~A}, \sim 2$-fold increase, $P=0.042$ ]. No significant differences in mRNA expression for $A B C B 1, A B C B 3, A B C C 2$ or $A B C G 2$ were observed between carboplatin resistant ovarian cancer cell lines (OVCAR-5 CBPR and CaOV3 CBPR) and parental cells (OVCAR-5 and CaOV3) [Figure 4B-E]. Similarly, no difference in mRNA expression for $A B C B 1, A B C B 3, A B C C 2$ or $A B C G 2$ was observed between primary HGSOC cells from patients with chemosensitive disease at diagnosis and patients with acquired chemotherapy resistance at relapse [Figure $4 \mathrm{~B}-\mathrm{E}$ ]. Increased $\mathrm{ABCA} 1$ protein expression was observed in both OVCAR-5 CBPR and CaOV3 CBPR compared to the parental cells by immunocytochemistry [Figure 5A-D]. ABCA1 was localized to both the cytoplasm and nucleus of the cells. No staining was observed in OVCAR-5 [Figure 5E] or CaOV3 cells [Figure 5F] incubated with rabbit IgG instead of ABCA1 antibody. Increased $\mathrm{ABCA} 1$ protein expression in OVCAR-5 CBPR and $\mathrm{CaOV} 3 \mathrm{CBPR}$ cells compared to the parental cells was confirmed by Western blotting [Figure $5 \mathrm{G}$ and $\mathrm{H}$ ]. 

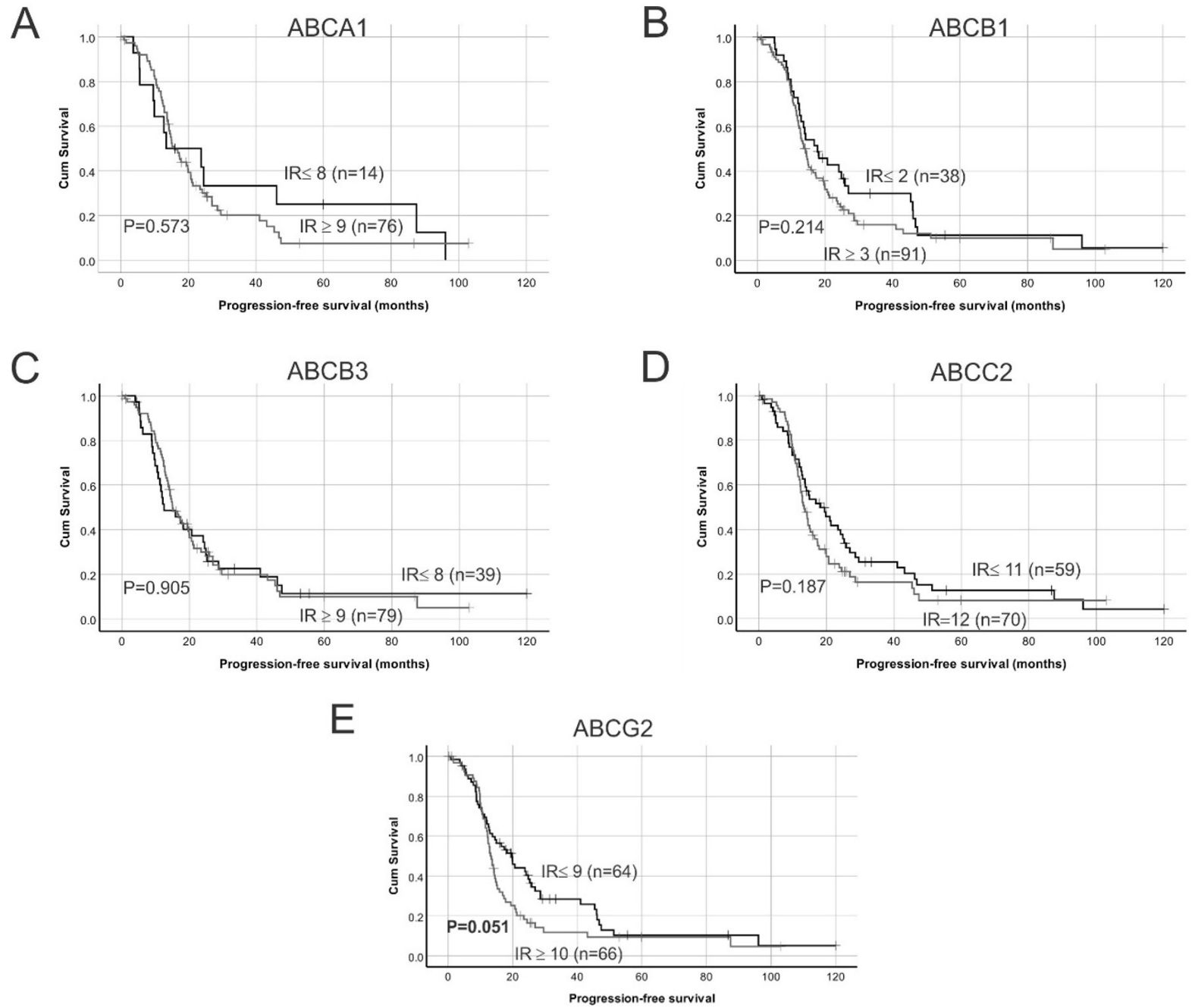

Figure 2. Kaplan-Meier survival analysis showing relationship between $A B C$ transporter protein expression and HGSOC patient progression-free survival (PFS). Median immunoreactive (IR) scores were used as cut-off points to separate samples into groups with low or high $A B C$ transporter protein expression: $(A)$ low $A B C A 1$ expression $(I R \leq 8)$ vs. high $A B C A 1$ expression $(I R \geq 9)$; (B) low $A B C B 1$ expression ( $I R \leq 2)$ vs. high $A B C B 1$ expression ( $I R \geq 3)$; (C) low $A B C B 3$ expression ( $I R \leq 8)$ vs. high $A B C B 3$ expression (IR $\geq 9)$; (D) low $A B C C 2$ expression ( $I R \leq 11)$ vs. high $A B C C 2$ expression ( $I R=12)$; and $(E)$ low $A B C G 2$ expression $(I R \leq 9)$ vs. high $A B C G 2$ expression (IR $\geq 10$ ). Data were analyzed using log rank test. IR:Immunoreactive score.

\section{Apabetalone reduces $A B C A 1$ expression and overcomes carboplatin resistance}

We investigated whether an inhibitor of ABCA1, apabetalone ${ }^{[10]}$, could decrease ABCA1 expression in ovarian cancer cell lines and increase their sensitivity to carboplatin. OVCAR-5 cells were treated for $48 \mathrm{~h}$ with increasing concentrations of apabetalone $(0-80 \mu \mathrm{M})$. Apabetalone treatment $(80 \mu \mathrm{M})$ for $48 \mathrm{~h}$ reduced ABCA1 protein expression in OVCAR-5 cells [Supplement Figure $3 \mathrm{~A}$ and B]. Cell survival of OVCAR-5 cells was inhibited following $72 \mathrm{~h}$ treatment with 40 and $80 \mu \mathrm{m}$ apabetalone [Supplement Figure 3C]. We confirmed that $80 \mu \mathrm{m}$ apabetalone treatment significantly inhibited ABCA1 protein expression in OVCAR-5 and matching carboplatin resistant cells OVCAR-5 CBPR cells [Figure 6A and B]. Co-treatment with apabetalone $(80 \mu \mathrm{M})$ increased the sensitivity to carboplatin for OVCAR-5 [Figure 6C] and $\mathrm{CaOV} 3$ [Figure 6D] cells and the matching carboplatin resistant cells [Figure $6 \mathrm{E}$ and $\mathrm{F}$ ]. The carboplatin $\mathrm{IC}_{50}$ was significantly reduced when parental or carboplatin resistant cell lines were co-treated with carboplatin and apabetalone [Figure $6 \mathrm{G}$ and $\mathrm{H}]$. The combination of apabetalone and carboplatin was synergistic in carboplatin-resistant cells (combination index $<1.0$ ) but not in carboplatin-sensitive cells [Supplement Figure 4]. 

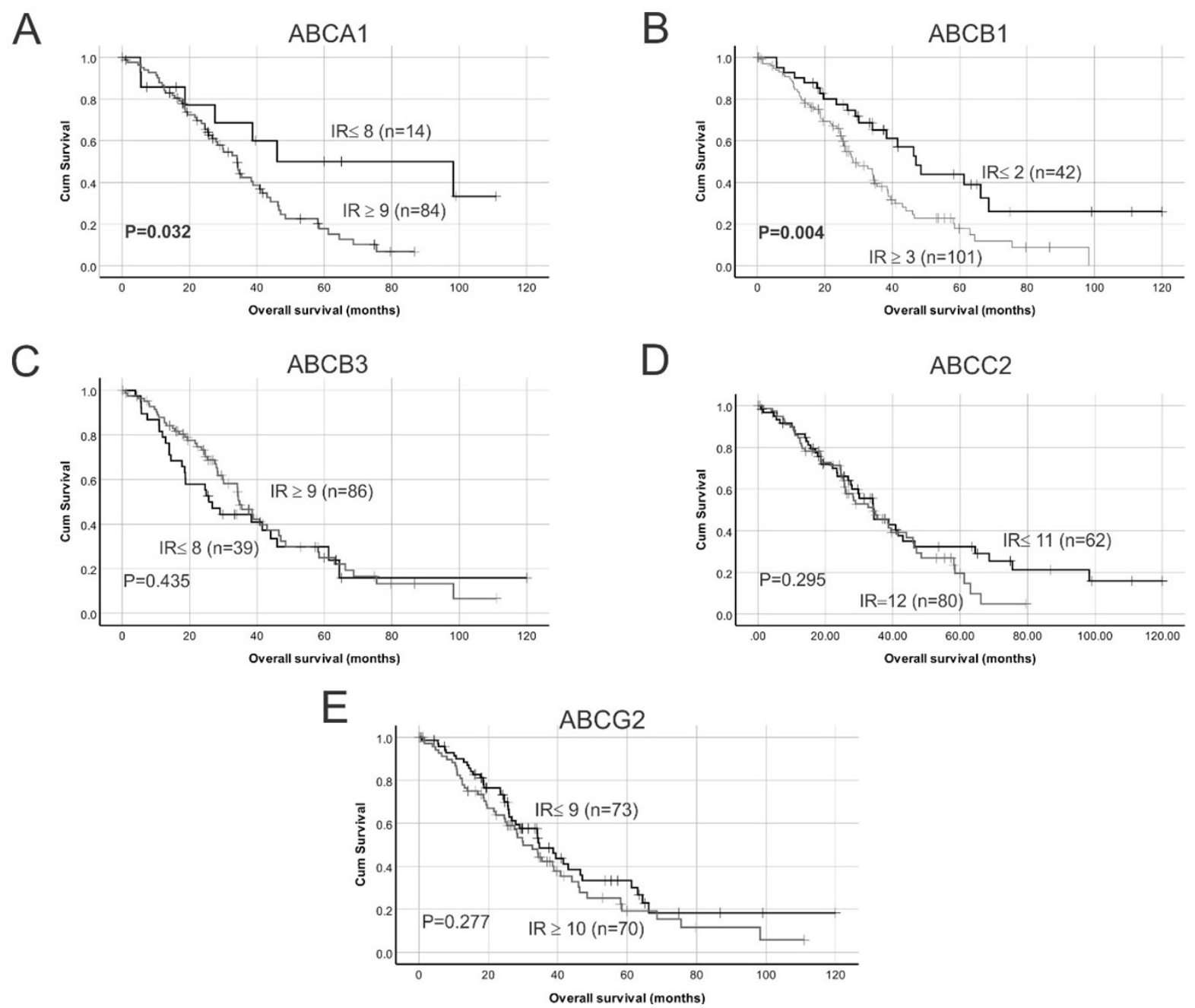

Figure 3. Kaplan-Meier survival analysis showing relationship between $A B C$ transporter protein expression and HGSOC overall survival. Median IR were used as cut-off points to separate samples into groups with low or high $A B C$ transporter protein expression: (A) low $A B C A 1$ expression $(I R \leq 8)$ vs. high $A B C A 1$ expression ( $I R \geq 9)$; $(B)$ low $A B C B 1$ expression $(I R \leq 2)$ vs. high $A B C B 1$ expression $(I R \geq 3)$; (C) low $A B C B 3$ expression $(I R \leq 8)$ vs. high $A B C B 3$ expression $(I R \geq 9)$; (D) low $A B C C 2$ expression $(I R \leq 11)$ vs. high $A B C C 2$ expression $(I R=12)$; and $(E)$ low $A B C G 2$ expression $(I R \leq 9)$ vs. high $A B C G 2$ expression $(I R \geq 10)$. Data were analyzed using log rank test. IR:Immunoreactive score.

Clinical trials evaluating three generations of $\mathrm{ABC}$ inhibitors (e.g., nicardipine, biricodar and sulindac) targeting specific transporters (e.g., $\mathrm{ABCB} 1$ and $\mathrm{ABCG} 2$ ) have failed because of immunosuppression, nephrotoxicity and interaction with chemotherapeutics ${ }^{[7,45-47]}$. The trials did not select patients by ABC transporter expression, and clinical trials targeted ABCB1 and ABCG2 (with only a few targeting $A B C C 2$ ), but other $A B C$ transporters also likely to play important roles in ovarian cancer progression and chemotherapy resistance ${ }^{[7]}$. Our results highlight that increased expression of ABCA1 is associated with development of acquired chemotherapy resistance and poor patient outcome.

ABCA1 is a transmembrane protein responsible for reverse cholesterol transport from inside cells into the blood ${ }^{[48]}$ and interacts with apolipoprotein A1 to bind cholesterol and synthesize high-density lipoproteins ${ }^{[49]}$. Both the overexpression and the downregulation of ABCA1 have been associated with tumorigenesis including ovarian cancer ${ }^{[11,12,50-55]}$. In this study, we showed that high $A B C A 1$ mRNA was significantly associated with both reduced PFS and PPS but not OS, while high protein ABCA1 expression 
Table 2. Cox regression analyses of $A B C$ transporter protein expression in the HGSOC TMA patient cohort

\begin{tabular}{|c|c|c|c|c|}
\hline \multirow{2}{*}{ Variable } & \multirow{2}{*}{$n$} & \multicolumn{3}{|c|}{ Overall survival } \\
\hline & & Relative risk & $95 \% \mathrm{Cl}$ & $P$ value \\
\hline \multicolumn{5}{|c|}{ (A) Univariate Cox Regression analyses for progression-free survival and overall survival } \\
\hline Age $^{\mathrm{a}}$ & 142 & 1.35 & $0.92-1.99$ & 0.172 \\
\hline Tumor stage ${ }^{b}$ & 143 & 0.93 & $0.37-2.30$ & 0.868 \\
\hline Tumor grade ${ }^{c}$ & 143 & 0.92 & $0.54-1.57$ & 0.759 \\
\hline Residual disease ${ }^{d}$ & 98 & 2.01 & $0.95-4.27$ & 0.069 \\
\hline$A B C A 1^{e}$ & 97 & 2.47 & $1.05-5.80$ & 0.037 \\
\hline$A B C B 1^{\dagger}$ & 140 & 2.04 & $1.24-3.34$ & 0.005 \\
\hline$A B C B 3^{g}$ & 123 & 0.83 & $0.52-1.33$ & 0.436 \\
\hline$A B C C 2^{h}$ & 139 & 1.26 & $0.82-1.95$ & 0.296 \\
\hline$A B C G 2^{i}$ & 140 & 1.29 & $0.85-1.96$ & 0.228 \\
\hline \multicolumn{5}{|c|}{ (B) Multivariate Cox Regression analyses for overall survival $(n=97)$} \\
\hline $\mathrm{ABCA} 1^{\mathrm{e}}$ & & 2.33 & $1.19-7.89$ & 0.050 \\
\hline $\mathrm{ABCB} 1^{\dagger}$ & & 1.93 & $0.25-0.89$ & 0.033 \\
\hline
\end{tabular}

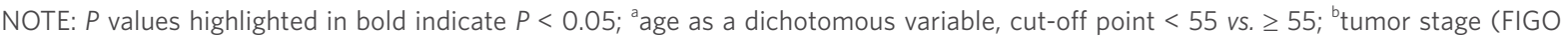
stage II + III vs. FIGO stage IV); ${ }^{c}$ tumors grade (moderate vs. poor); ${ }^{d}$ residual disease status (negative vs. positive); ${ }^{\mathrm{e}} \mathrm{ABCA}$ (IR) in cancer cells as a dichotomous variable, cut-off point $\leq 8 \mathrm{vs} . \geq 9$ (only 5/7 TMA slides available for the immunostaining); ${ }^{\dagger} A B C B 1$ (IR) in cancer cells as a dichotomous variable, cut-off point $\leq 2 \mathrm{vs} . \geq 3 ;{ }^{8} A B C B 3$ (IR) in cancer cells as a dichotomous variable, cut-off point $\leq 8$ vs. $\geq 9$; ${ }^{\mathrm{h}} \mathrm{ABCC} 2$ (IR) in cancer cells as a dichotomous variable, cut-off point $\leq 11 \mathrm{vs} . \geq 12$; ${ }^{\mathrm{A}} \mathrm{ABCG}$ (IR) in cancer cells as a dichotomous variable, cut-off point $\leq 9$ vs. $\geq 10$; IR: immunoreactive score.

was associated with reduced OS. Together, our findings are in agreement with a previous study showing that high $A B C A 1$ mRNA expression was associated with reduced PFS and OS in ovarian cancer patients from The Cancer Genome Atlas (TCGA, $n=407)^{[11]}$ The same study also found reduced PFS and OS in HGSOC patients with high ABCA1 protein expression $(n=91)^{[11]}$. However, another study observed that low ABCA1 protein expression was associated with reduced PFS $(n=55, P=0.038)^{[51]}$. This disparate finding may be due to the smaller cohort size, including different ovarian cancer subtypes and a mixture of both low- and high-grade disease, varied chemotherapy treatment, different methods of assessment and the use different antibodies to detect $\mathrm{ABCA}$.

Increased $\mathrm{ABCA} 1 \mathrm{mRNA}$ and protein expression were observed in both carboplatin-resistant OVCAR-5 and $\mathrm{CaOV} 3$ cell lines compared to the parental cells and correlated with the 2-3-fold increase in carboplatin $\mathrm{IC}_{50}$. A similar fold increase in $A B C A 1$ expression was observed between primary cells from patients with chemosensitive disease and acquired chemotherapy resistance. The first evidence for the role of $A B C A 1$ in platinum chemotherapy resistance comes from a study that demonstrated increased $A B C A 1$ mRNA expression in a cisplatin resistant epidermoid carcinoma cell line $(\mathrm{KCP}-4)^{[56]}$. Lentiviral knockdown of $A B C A 1$ in KCP-4 cells resulted in the re-sensitization to cisplatin ${ }^{[56]}$. A more recent study investigating drug-resistant tumor cell phenotypes in the ascitic fluid of epithelial ovarian cancer patients identified that a population of cells that were EpCAM ${ }^{+} \mathrm{CD} 45^{+}$were more resistant compared to EpCAM ${ }^{+}$tumor cells and overexpressed $A B C A 1^{[57]}$. A limitation of our study was not performing knockdown of $A B C A 1$ to demonstrate reversal of carboplatin resistance.

This study found that increased $\mathrm{ABCB} 1$ protein expression was associated with reduced OS in HGSOC. It is not clear why $A B C B 1 \mathrm{mRNA}$ and protein expression results are contrasting, but discord may be due increased mRNA turnover ${ }^{[58]}$ or mRNA instability ${ }^{[59]}$ compared to protein half-life $^{[60]}$. Our findings are in agreement with previous HGSOC studies demonstrating a significant relationship between ABCB1 protein expression and reduced OS $\left(n=60, P=0.015^{[14]} ; n=52, P<0.0005^{[13]}\right)$. A more recent study found a significant relationship between high $A B C B 1$ expression and reduced PFS $(n=143, P=0.003)$ in patients with $\mathrm{HGSOC}^{[61]}$. Although increased $\mathrm{ABCB} 1 \mathrm{mRNA}$ and protein expression have been shown in 

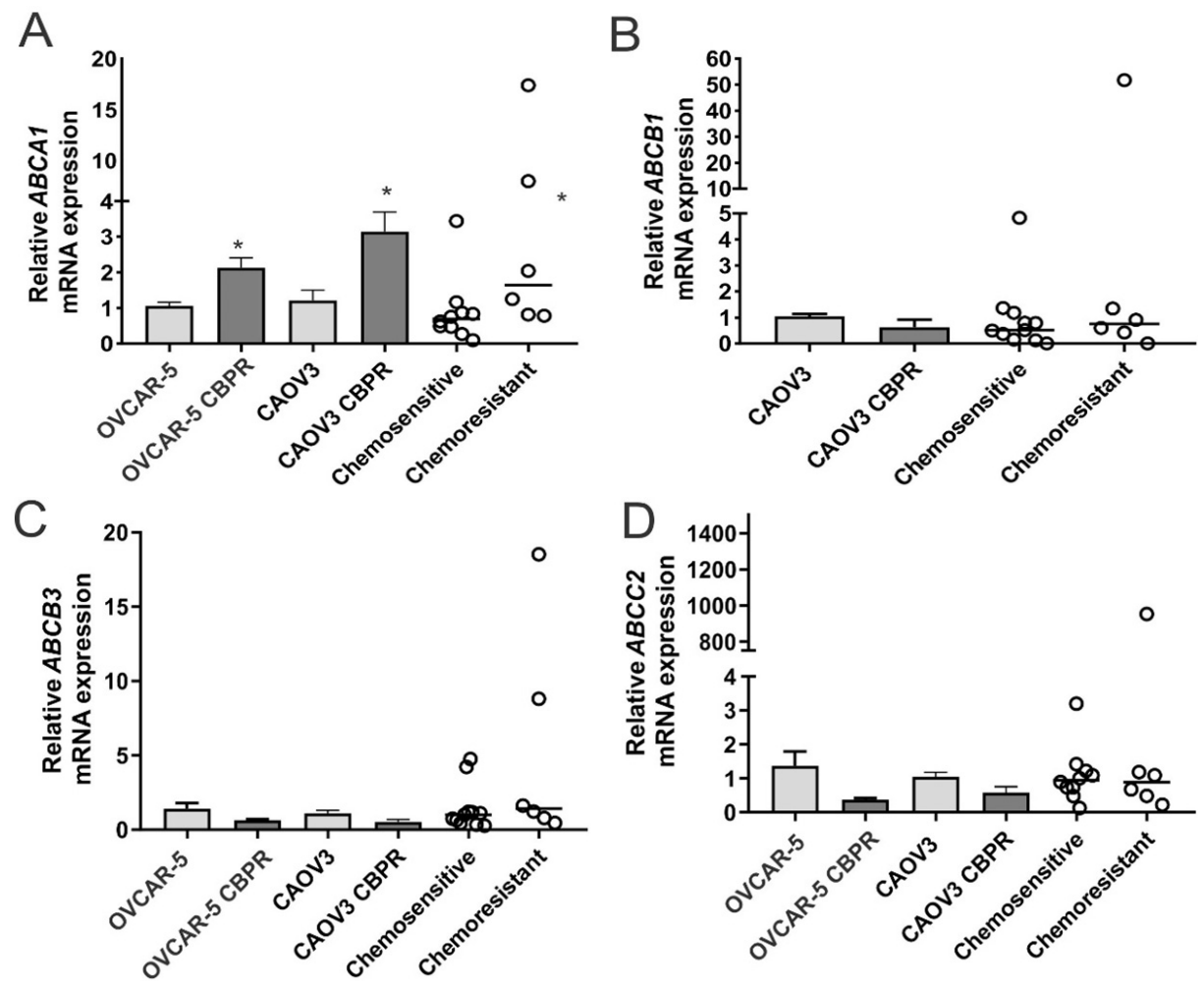

$\mathrm{E}$

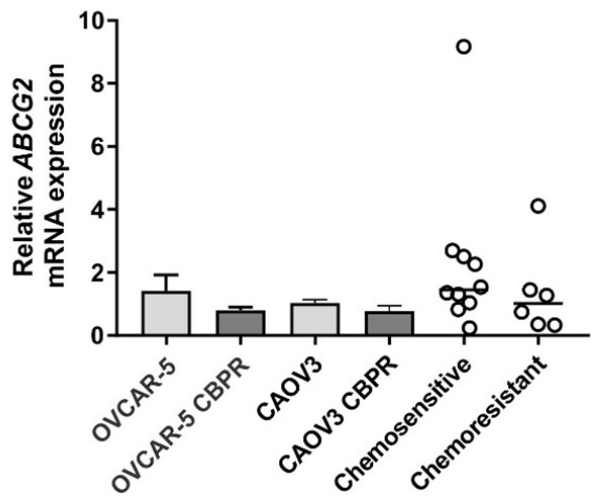

Figure 4. $A B C A 1$ mRNA expression is increased in ovarian cancer cells with acquired carboplatin resistance. (A) $A B C A 1 ;(B) A B C B 1 ;(C)$ $A B C B 3$; (D) $A B C C 2$; and (E) ABCG2 expression in parental (OVCAR-5 and $\mathrm{CaOV} 3$ ) and carboplatin resistant ovarian cancer cell lines (OVCAR-5 CBPR and CaOV3 CBPR). For the cell line, the columns represent the mean fold changes \pm SEM from 12-20 RNA samples from 4-6 independent experiments. ${ }^{\star} P<0.05$, unpaired $t$ test. Data for the primary HGSOC cells from patients with chemosensitive at diagnosis $(n=9)$ or acquired chemoresistance following relapse $(n=6)$ are expressed as the median fold change from 3-6 RNA samples from two independent experiments. ${ }^{\star} P=0.026$, Mann-Whitney $U$ test. ABCB1 was not detectable in OVCAR-5 cells.

chemoresistant ovarian cancer cell lines ${ }^{[62-66]}$, our study found no significant relationship between $A B C B 1$ expression and carboplatin-resistance. $\mathrm{ABCB} 1$ is expressed in ovarian tumors which have been treated with paclitaxel, but not in chemonaive cancers or cancers exposed to other chemotherapy drugs such as cisplatin that are not substrates for $\mathrm{ABCB} 1^{[7,67-69]}$.

We found high $A B C B 3$ mRNA expression was significantly associated with increased PFS, PPS and OS when only HGSOC patients were included in the analysis. In contrast, no significant relationship was observed between $\mathrm{ABCB} 3$ protein expression levels and patient outcome. This may be due to reduced mRNA turnover ${ }^{[58]}$ or increased mRNA stability ${ }^{[59]}$ compared to protein half-life ${ }^{[60]}$. Our findings agree with 

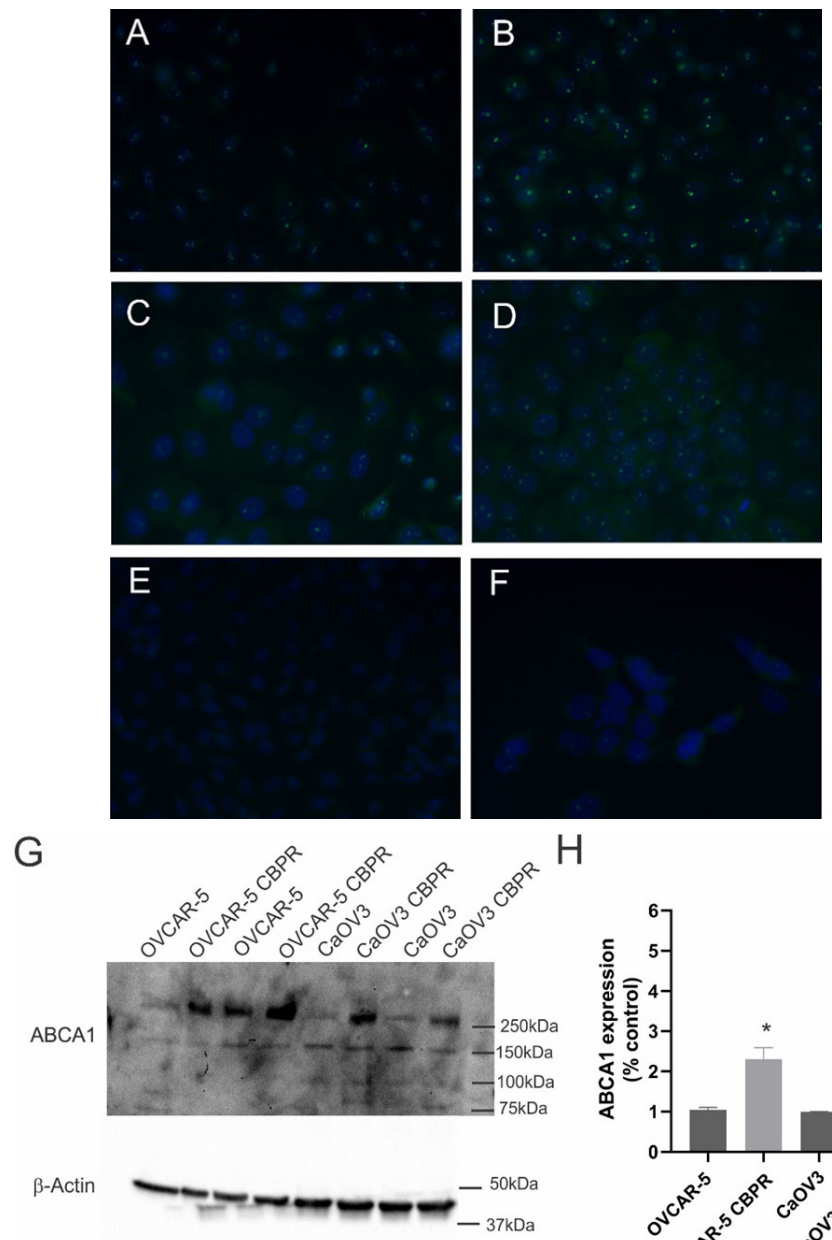

$\mathrm{H}$

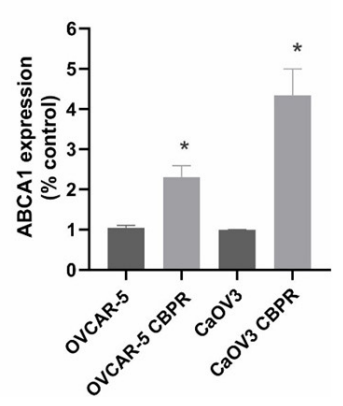

Figure 5. $A B C A 1$ protein expression is upregulated in ovarian cancer cells with acquired carboplatin resistance. $A B C A 1$ expression in OVCAR-5 (A) and CaOV3 (C) and carboplatin resistant OVCAR-5 CBPR (B) and CaOV3 CBPR (D) by immunocytochemistry using rabbit polyclonal ABCA1 antibody (1/100, NB400-105, Novus Biological). (E) OVCAR-5 cells with Rabbit IgG and (F) CaOV3 cells with Rabbit IgG. (G) Protein extracts from OVCAR-5 $(\sim 30 \mu \mathrm{g})$ and CaOV3 cell lines $(\sim 60 \mu \mathrm{g})$ were electrophoresed and immunoblotted with rabbit polyclonal ABCA1 antibody (1/1000, NB400-105, Novus Biological), and $\beta$-actin (1/2000, Abcam) was used as a loading control. A major band was detected at $\sim 250 \mathrm{kDa}$, which is the predicted size for ABCA1. (H) Quantitation of ABCA1 Western blots. Data are from 2-4 independent experiments. Statistical significance was determined using the Student's $t$-test, ${ }^{\star} P<0.05$.

a large cohort study ( $n=232$ EOC including $n=128$ serous OC) that observed no association between $\mathrm{ABCB} 3$ protein expression and clinical outcome $\mathrm{e}^{[21]}$.

$\mathrm{ABCB} 3$ was upregulated in breast cancers following treatment with neo-adjuvant chemotherapy and increased in recurrent ovarian cancers ${ }^{[19,70]}$. Our previous study also showed higher ABCB3 protein levels in ovarian cancer tissues after neoadjuvant carboplatin treatment and after recurrence compared with tissues from untreated ovarian cancers ${ }^{[7]}$. Although these studies suggested a link between ABCB3 expression and chemotherapy resistance, our study did not find a relationship between $\mathrm{ABCB} 3$ expression and acquired chemotherapy resistance.

ABCC2 mRNA or protein levels have been shown to be associated with ovarian cancer outcome ${ }^{[19,22,23]}$, but several other studies did not find a relationship with patient outcome ${ }^{[24,25,71,72]}$. In our analysis, we found that high ABCC2 mRNA expression was significantly associated with reduced PPS in all ovarian cancer and HGSOC, but we did not find any relationship between patient outcome and ABCC2 protein expression. 

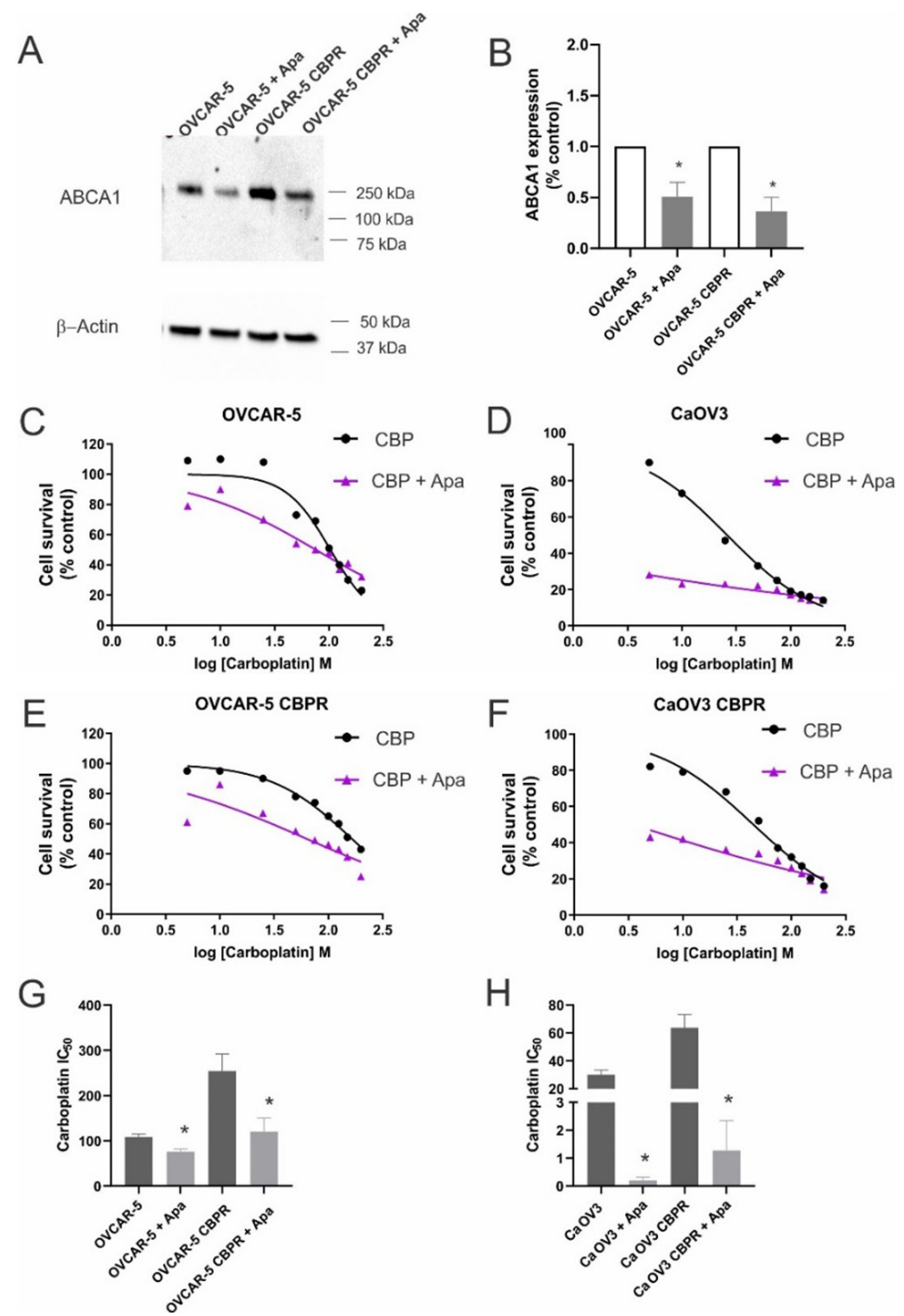

Figure 6. Effects of apabetalone on $A B C A 1$ expression and carboplatin response in ovarian cancer cells. (A) Apabetalone treatment reduced expression of ABCA1 in OVCAR- 5 and OVCAR- 5 CBPR cell lines. Cells were treated for $72 \mathrm{~h}$ with control medium (DMSO) or apabetalone $(80 \mu \mathrm{M})$. Protein extracts from OVCAR-5 $(\sim 30 \mu \mathrm{g})$ were electrophoresed and immunoblotted with rabbit polyclonal ABCA1 antibody (1/1000, NB400-105, Novus Biological) and $\beta$-actin (1/2000, Abcam) was used as a loading control. (B) Quantification of Western blot. OVCAR-5 (C), CaOV3 (D), OVCAR-5 CBPR (E) and CaOV3 CBPR (F) cell survival following treatment with carboplatin (CBP) alone (0-200 $\mu \mathrm{M}$, black line) and in combination with apabetalone (Apa, $80 \mu \mathrm{M}$, purple line). (G) Carboplatin IC Fo $_{5}$ for OVCAR-5 and OVCAR-5 CBPR cells \pm apabetalone. Data are mean \pm SEM from three independent experiments. ${ }^{*} P<0.05$, Student's $t$-test. (H) Carboplatin $\mathrm{IC}_{50}$ for $\mathrm{CaOV} 3$ and $\mathrm{CaOV} 3 \mathrm{CBPR}$ cells \pm apabetalone. Data are mean \pm SEM from three independent experiments. $P<0.05$, Student's $t$-test.

The reasons for the inconsistency are unknown, but it may due to the use of small patient cohorts, inclusion of different ovarian cancer subtypes and the use of different primary antibodies. Another explanation for the discrepancy may be due to the ABCC2 localization within the cell. Surowiak et al ${ }^{[22]}$ found that higher nuclear ABCC2 levels both before and after chemotherapy were associated with cisplatin resistance and shorter survival time. A limitation of our study was not assessing nuclear expression of ABCC2. Although previous studies found ABCC2 mRNA and protein expression to be increased by carboplatin treatment and following recurrence ${ }^{[7,19,42]}$, in this study, we did not find a relationship between ABCC2 expression and acquired chemotherapy resistance. This observation is consistent with previous studies that did not observe a relationship between platinum response and $\mathrm{ABCC} 2 \mathrm{mRNA}$ or protein expression ${ }^{[25,71-74]}$.

High ABCG2 protein levels but not ABCG2 mRNA expression were significantly associated with reduced 
PFS in HGSOC patient tissues in this study. It is not clear why ABCG2 mRNA and protein expression results are contrasting, but discord may be due to increased mRNA turnover ${ }^{[58]}$ or mRNA instability ${ }^{[59]}$ compared to protein half-life ${ }^{[60]}$. Several studies have investigated the relationship between $A B C G 2$ genotype variants with ovarian cancer outcome. One study found no relationship between a variant $A B C G 2$ and clinical outcome in a large mixed subtype cohort of ovarian cancer patients $(n=914)^{[75]}$ while a more recent study found that a $A B C G 2$ variant (C421A) previously linked with enhanced protein degradation and drug sensitivity ${ }^{[76]}$ was associated with longer PFS in patients with advanced stage epithelial ovarian cancer treated with platinum + paclitaxel-based chemotherapy ${ }^{[77]}$.

ABCG2 is a marker of ovarian cancer stem cells and highly expressed in ovarian cancer spheroids which have higher chemoresistance to cisplatin or paclitaxel ${ }^{[27,78]}$. However, we did not observe a significant relationship between ABCG2 expression and acquired chemoresistance, which is in agreement with another study that did not observe any difference in ABCG2 expression in A2780 ovarian cancer cell treated with cisplatin ${ }^{[79]}$. However, a significant overexpression of ABCG2 mRNA and protein was observed in topotecan-resistant ovarian cancer cell lines ${ }^{[80,81]}$. Another study challenged ovarian cancer cell lines with six different chemotherapies and found increased ABCG2 mRNA expression in vincristine$(P<0.01)$ and topotecan-resistant $(P<0.001)$ cell lines ${ }^{[63]}$. Together, the data indicate that ABCG2 is not increased following carboplatin chemotherapy treatment but may play a role in chemoresistance to other chemotherapy drugs including vincristine and topotecan.

Apabetalone has recently been shown to inhibit ABCA1 protein expression in Caco-2 colon cancer cells and inhibit tumor promoting behavior including proliferation, migration, invasion and reverse the EMT phenotype observed in ABCA1 overexpressing Caco-2 cells ${ }^{[10]}$. Importantly, treatment with apabetalone significantly decreased cholesterol transport in both control cells and ABCA1 overexpressing Caco-2 cells $^{[10]}$. In our study, we found that apabetalone treatment also reduced ABCA1 protein expression and increased the sensitivity of ovarian cancer cell lines to carboplatin. Apabetalone is a bromodomain and extra-terminal (BET) inhibitor that has recently been investigated for the treatment of atherosclerosis in clinical trials ${ }^{[82,83]}$. The concentration of apabetalone used in our experiments was similar to that used in in vitro studies using colon cancer cell lines ${ }^{[10]}$ and hepatocytes ${ }^{[84]}$. Apabetalone appears to be well tolerated in humans (50-150 mg twice/day ${ }^{[82,85]}$ ) and mice $(150 \mathrm{mg} / \mathrm{kg} \text { b.i.d for } 14 \text { weeks })^{[86]}$. Pharmacokinetic studies in humans administering $100 \mathrm{mg}$ apabetalone have observed a peak plasma concentration of $360 \mathrm{ng} / \mathrm{mL}(\sim 1 \mu \mathrm{M})$ after $3.5 \mathrm{~h}$ treatment ${ }^{[87]}$, which is considerably lower than the concentration used in our study. Further experiments need to be performed to examine the feasibility of using apabetalone and the doses required to reduce $\mathrm{ABCA} 1$ expression in in vivo ovarian cancer models.

In conclusion, we provided evidence for the role of $\mathrm{ABCA} 1$ in ovarian cancer acquired carboplatin resistance and progression. Our study found that high ABCA1 mRNA and protein expression was significantly associated with poor clinical outcome and increased in ovarian cancer cell lines and primary serous ovarian cancer cells following acquired chemotherapy resistance. Developing strategies to inhibit ABCA1 expression has potential to overcome chemotherapy resistance and improve ovarian cancer survival.

\section{DECLARATIONS}

\section{Acknowledgments}

The authors thank Prof Andrew Ruszkiewicz for his help with TMA preparation.

\section{Authors' contributions}

Experimental design: Wang W, Ricciardelli C Methodology and data collection: Wang W, Lokman NA, Macpherson AM, Noye TM Analysis and interpretation of data: Wang W, Ricciardelli C, Lokman NA 
Writing-original draft preparation: Wang W, Ricciardelli C

Writing-review and editing: Ricciardelli C, Lokman NA, Macpherson AM, Oehler MK

Supervision: Ricciardelli C, Lokman NA, Oehler MK

Funding acquisition: Ricciardelli C, Oehler MK

All authors have read and agreed to the published version of the manuscript.

\section{Availability of data and materials}

Not applicable.

\section{Financial support and sponsorship}

This research has been funded by the Ovarian Cancer Research Foundation, Australia (Oehler MK). Ricciardelli C is currently supported by the Lin Huddleston Ovarian Cancer Fellowship funded by the Cancer Council South Australia and the Adelaide Medical School, University of Adelaide.

\section{Conflicts of interest}

All authors declared that there are no conflicts of interest.

\section{Consent for publication}

Not applicable.

\section{Ethical approval and consent to participate}

The TMA work was conducted with patient consent and approval by the Royal Adelaide Hospital Human Ethics Committee (RAH protocols \# 060903 \& RAH Protocol \# 140201). The experiments with primary cells were performed with patient consent and ethics approval by the Royal Adelaide Hospital Human Ethics Committee (RAH Protocol \# 140201) and Central Adelaide Local Health Network Human Ethics Committees (CALHN \# R20181215).

\section{Copyright}

(c) The Author(s) 2021.

\section{REFERENCES}

1. Siegel RL, Miller KD, Jemal A. Cancer statistics, 2020. CA Cancer J Clin 2020;70:7-30.

2. 2019 AIHW. Cancer in Australia 2019. In. Cancer series Canberra: AIHW: Australian Institute of Health and Welfare $2019 ; 2019$. Available from https://www.aihw.gov.au/reports/cancer/cancer-in-australia-2019/data [Last accessed on 19 Feb 2021]

3. Helleman J, Jansen MP, Burger C, van der Burg ME, Berns EM. Integrated genomics of chemotherapy resistant ovarian cancer: a role for extracellular matrix, TGFbeta and regulating microRNAs. Int J Biochem Cell Biol 2010;42:25-30.

4. Chien J, Kuang R, Landen C, Shridhar V. Platinum-sensitive recurrence in ovarian cancer: the role of tumor microenvironment. Front Oncol 2013;3:251.

5. Etemadmoghadam D, deFazio A, Beroukhim R, et al. Integrated genome-wide DNA copy number and expression analysis identifies distinct mechanisms of primary chemoresistance in ovarian carcinomas. Clin Cancer Res 2009;15:1417-27.

6. Bukowski K, Kciuk M, Kontek R. Mechanisms of Multidrug Resistance in Cancer Chemotherapy. Int J Mol Sci 2020;21.

7. Ween MP, Armstrong MA, Oehler MK, Ricciardelli C. The role of ABC transporters in ovarian cancer progression and chemoresistance. Crit Rev Oncol Hematol 2015;96:220-56.

8. Cerovska E, Elsnerova K, Vaclavikova R, Soucek P. The role of membrane transporters in ovarian cancer chemoresistance and prognosis. Expert Opin Drug Metab Toxicol 2017;13:741-53.

9. Yvan-Charvet L, Wang N, Tall AR. Role of HDL, ABCA1, and ABCG1 transporters in cholesterol efflux and immune responses. Arterioscler Thromb Vasc Biol 2010;30:139-43.

10. Aguirre-Portoles C, Feliu J, Reglero G, Ramirez de Molina A. ABCA1 overexpression worsens colorectal cancer prognosis by facilitating tumour growth and caveolin-1-dependent invasiveness, and these effects can be ameliorated using the BET inhibitor apabetalone. Mol Oncol 2018;12:1735-52.

11. Hedditch EL, Gao B, Russell AJ, et al. ABCA transporter gene expression and poor outcome in epithelial ovarian cancer. J Natl Cancer Inst 2014;106:dju149.

12. Schimanski S, Wild PJ, Treeck O, et al. Expression of the lipid transporters ABCA3 and ABCA1 is diminished in human breast cancer 
tissue. Horm Metab Res 2010;42:102-9.

13. Raspollini MR, Amunni G, Villanucci A, Boddi V, Taddei GL. Increased cyclooxygenase-2 (COX-2) and P-glycoprotein-170 (MDR1) expression is associated with chemotherapy resistance and poor prognosis. Analysis in ovarian carcinoma patients with low and high survival. Int J Gynecol Cancer 2005; 15:255-60.

14. Yakirevich E, Sabo E, Naroditsky I, et al. Multidrug resistance-related phenotype and apoptosis-related protein expression in ovarian serous carcinomas. Gynecol Oncol 2006;100:152-9.

15. Chen H, Hao J, Wang L, Li Y. Coexpression of invasive markers (uPA, CD44) and multiple drug-resistance proteins (MDR1, MRP2) is correlated with epithelial ovarian cancer progression. Br J Cancer 2009;101:432-40.

16. Sedlakova I, Laco J, Caltova K, et al. Clinical significance of the resistance proteins LRP, Pgp, MRP1, MRP3, and MRP5 in epithelial ovarian cancer. Int J Gynecol Cancer 2015;25:236-43.

17. Arts HJ, Katsaros D, de Vries EG, et al. Drug resistance-associated markers P-glycoprotein, multidrug resistance-associated protein 1, multidrug resistance-associated protein 2, and lung resistance protein as prognostic factors in ovarian carcinoma. Clin Cancer Res 1999;5:2798-805.

18. Huang X, Ushijima K, Komai K, et al. Co-expression of $\mathrm{Y}$ box-binding protein-1 and P-glycoprotein as a prognostic marker for survival in epithelial ovarian cancer. Gynecol Oncol 2004;93:287-91.

19. Auner V, Sehouli J, Oskay-Oezcelik G, Horvat R, Speiser P, Zeillinger R. ABC transporter gene expression in benign and malignant ovarian tissue. Gynecol Oncol 2010;117:198-201.

20. Han LY, Fletcher MS, Urbauer DL, et al. HLA class I antigen processing machinery component expression and intratumoral T-Cell infiltrate as independent prognostic markers in ovarian carcinoma. Clin Cancer Res 2008;14:3372-9.

21. Leffers N, Gooden MJM, Mokhova AA, et al. Down-regulation of proteasomal subunit MB1 is an independent predictor of improved survival in ovarian cancer. Gynecol Oncol 2009;113:256-63.

22. Surowiak P, Materna V, Kaplenko I, et al. ABCC2 (MRP2, cMOAT) can be localized in the nuclear membrane of ovarian carcinomas and correlates with resistance to cisplatin and clinical outcome. Clin Cancer Res 2006;12:7149-58.

23. Kim H, Kim K, No JH, Jeon YT, Jeon HW, Kim YB. Prognostic Value of Biomarkers Related to Drug Resistance in Patients with Advanced Epithelial Ovarian Cancer. Anticancer Res 2012;32:589-94.

24. Ohishi Y, Oda Y, Uchiumi T, Kobayashi H, et al. ATP-binding cassette superfamily transporter gene expression in human primary ovarian carcinoma. Clin Cancer Res 2002;8:3767-75.

25. Guminski AD, Balleine RL, Chiew YE, et al. MRP2 (ABCC2) and cisplatin sensitivity in hepatocytes and human ovarian carcinoma. Gynecol Oncol 2006;100:239-46.

26. Zhang W, Yu F, Wang Y, Zhang Y, Meng L, Chi Y. Rab23 promotes the cisplatin resistance of ovarian cancer via the Shh-Gli-ABCG2 signaling pathway. Oncol Lett 2018;15:5155-60.

27. Zhang S, Balch $\mathrm{C}$, Chan MW, et al. Identification and characterization of ovarian cancer-initiating cells from primary human tumors. Cancer Res 2008;68:4311-20.

28. Gyorffy B, Lanczky A, Szallasi Z. Implementing an online tool for genome-wide validation of survival-associated biomarkers in ovariancancer using microarray data from 1287 patients. Endoc Relat Cancer 2012;19:197-208.

29. Ricciardelli C, Lokman NA, Pyragius CE, et al. Keratin 5 overexpression is associated with serous ovarian cancer recurrence and chemotherapy resistance. Oncotarget 2017;8:17819-32.

30. Allahverdian S, Chehroudi AC, McManus BM, Abraham T, Francis GA. Contribution of intimal smooth muscle cells to cholesterol accumulation and macrophage-like cells in human atherosclerosis. Circulation 2014;129:1551-9.

31. Margaryan NV, Hazard-Jenkins H, Salkeni MA, et al. The Stem Cell Phenotype of Aggressive Breast Cancer Cells. Cancers (Basel) 2019;11:340.

32. Chu TM, Kawinski E, Lin TH. Characterization of a new monoclonal antibody F4 detecting cell surface epitope and P-glycoprotein in drug-resistant human tumor cell lines. Hybridoma 1993;12:417-29.

33. Surowiak P, Materna V, Kaplenko I, et al. ABCC2 (MRP2, cMOAT) can be localized in the nuclear membrane of ovarian carcinomas and correlates with resistance to cisplatin and clinical outcome. Clin Cancer Res 2006;12:7149-58.

34. Maliepaard M, Scheffer GL, Faneyte IF, et al. Subcellular localization and distribution of the breast cancer resistance protein transporter in normal human tissues. Cancer Res 2001;61:3458-64.

35. Brunham LR, Kruit JK, Pape TD, et al. Tissue-specific induction of intestinal ABCA1 expression with a liver X receptor agonist raises plasma HDL cholesterol levels. Circ Res 2006;99:672-4.

36. Andersen V, Svenningsen K, Knudsen LA, et al. Novel understanding of ABC transporters ABCB1/MDR/P-glycoprotein, ABCC2/MRP2, and ABCG2/BCRP in colorectal pathophysiology. World J Gastroenterol 2015;21:11862-76.

37. Drozdzik M, Busch D, Lapczuk J, et al. Protein Abundance of Clinically Relevant Drug Transporters in the Human Liver and Intestine: A Comparative Analysis in Paired Tissue Specimens. Clin Pharmacol Ther 2019;105:1204-12.

38. Mutch DM, Anderle P, Fiaux M, et al. Regional variations in ABC transporter expression along the mouse intestinal tract. Physiol Genomics 2004; 17:11-20.

39. Jedlitschky G, Hoffmann U, Kroemer HK. Structure and function of the MRP2 (ABCC2) protein and its role in drug disposition. Expert Opin Drug Metab Toxicol 2006;2:351-66.

40. Feng Z, Wen H, Ju XZ, et al. Expression of hypothalamic-pituitary-gonadal axis-related hormone receptors in low-grade serous ovarian cancer (LGSC). J Ovarian Res 2017;10:7.

41. Ricciardelli C, Lokman NA, Cheruvu S. Transketolase is upregulated in metastatic peritoneal implants and promotes ovarian cancer cell 
proliferation. Clin Exp Metastasis 2015;32:441-55.

42. Ricciardelli C, Ween MP, Lokman NA, Tan IA, Pyragius CE, Oehler MK. Chemotherapy-induced hyaluronan production: a novel chemoresistance mechanism in ovarian cancer. BMC Cancer 2013;13:476.

43. Chou TC. Drug combination studies and their synergy quantification using the Chou-Talalay method. Cancer Res 2010;70:440-6.

44. Ween MP, Lokman NA, Hoffmann P, Rodgers RJ, Ricciardelli C, Oehler MK. Transforming growth factor-beta-induced protein secreted by peritoneal cells increases the metastatic potential of ovarian cancer cells. Int J Cancer 2011;128:1570-84.

45. Shukla S, Ambudkar W, Suresh V, Ambudkar S. Development of inhibitors of ATP-binding cassette drug transporters: present status and challenges. Expert Opin Drug Metab Toxicol 2008;4:205-23.

46. Martin C, Berridge G, Mistry P, Higgins C, Charlton P, Callaghan R. The molecular interaction of the high affinity reversal agent XR9576 with P-glycoprotein. Br J Pharmacol 1999;128:403-11.

47. Liu KJ, Jh H, Su XD, et al. Saracatinib (AZD0530) is a potent modulator of ABCB1-mediated multidrug resistance in vitro and in vivo. Int J Cancer 2013;132:224-35.

48. Oram JF, Lawn RM. ABCA1. The gatekeeper for eliminating excess tissue cholesterol. J Lipid Res 2001;42:1173-9.

49. Wang N, Tall AR. Regulation and mechanisms of ATP-binding cassette transporter A1-mediated cellular cholesterol efflux. Arterioscler Thromb Vasc Biol 2003;23:1178-84.

50. Bi DP, Yin CH, Zhang XY, Yang NN, Xu JY. MiR-183 functions as an oncogene by targeting ABCA1 in colon cancer. Oncol Rep 2016;35:2873-9.

51. Chou JL, Huang RL, Shay J, et al. Hypermethylation of the TGF-beta target, ABCA1 is associated with poor prognosis in ovarian cancer patients. Clin Epigenetics 2015;7:1.

52. Lee BH, Taylor MG, Robinet P. Dysregulation of cholesterol homeostasis in human prostate cancer through loss of ABCA1. Cancer Res 2013;73:1211-8.

53. Smith B, Land H. Anticancer activity of the cholesterol exporter ABCA1 gene. Cell Rep 2012;2:580-90.

54. Vargas T, Moreno-Rubio J, Herranz J, et al. ColoLipidGene: signature of lipid metabolism-related genes to predict prognosis in stage-II colon cancer patients. Oncotarget 2015;6:7348-63.

55. Sekine Y, Demosky SJ, Stonik JA, et al. High-density lipoprotein induces proliferation and migration of human prostate androgenindependent cancer cells by an ABCA1-dependent mechanism. Mol Cancer Res 2010;8:1284-94.

56. Oiso S, Takayama Y, Nakazaki R, et al. Factors involved in the cisplatin resistance of KCP4 human epidermoid carcinoma cells. Oncol Rep 2014;31:719-26.

57. Akhter MZ, Sharawat SK, Kumar V, et al. Aggressive serous epithelial ovarian cancer is potentially propagated by $\mathrm{EpCAM}^{+} \mathrm{CD} 45^{+}$ phenotype. Oncogene 2018;37:2089-103.

58. Chrusciel M, Ponikwicka-Tyszko D, Wolczynski S, Huhtaniemi I, Rahman NA. Extragonadal FSHR Expression and Function-Is It Real? Front Endocrinol (Lausanne) 2019;10:32.

59. Nouaille S, Mondeil S, Finoux AL, Moulis C, Girbal L, Cocaign-Bousquet M. The stability of an mRNA is influenced by its concentration: a potential physical mechanism to regulate gene expression. Nucleic Acids Res 2017;45:11711-24.

60. Rahman M, Sadygov RG. Predicting the protein half-life in tissue from its cellular properties. PLoS One 2017;12:e180428.

61. Johnatty SE, Beesley J, Gao B, et al. ABCB1 (MDR1) polymorphisms and ovarian cancer progression and survival: a comprehensive analysis from the Ovarian Cancer Association Consortium and The Cancer Genome Atlas. Gynecol Oncol 2013;131:8-14.

62. Duan Z, Brakora KA, Seiden MV. Inhibition of ABCB1 (MDR1) and ABCB4 (MDR3) expression by small interfering RNA and reversal of paclitaxel resistance in human ovarian cancer cells. Mol Cancer Ther 2004;3:833-8.

63. Januchowski R, Wojtowicz K, Sujka-Kordowska P, Andrzejewska M, Zabel M. MDR Gene Expression Analysis of Six Drug-Resistant Ovarian Cancer Cell Lines. Biomed Res Int 2013;2013:241763-11.

64. Kiguchi K, Iwamori Y, Suzuki N, et al. Characteristic expression of globotriaosyl ceramide in human ovarian carcinoma-derived cells with anticancer drug resistance. Cancer Sci 2006;97:1321-6.

65. Ho EA, Soo PL, Allen C, Piquette-Miller M. Impact of intraperitoneal, sustained delivery of paclitaxel on the expression of P-glycoprotein in ovarian tumors. $J$ Control Release 2007;117:20-7.

66. Veneroni S, Zaffaroni N, Daidone MG, Benini E, Villa R, Silvestrini R. Expression of P-glycoprotein and in vitro or in vivo resistance to doxorubicin and cisplatin in breast and ovarian cancers. Eur J Cancer 1994;30A:1002-7.

67. Bourhis J, Goldstein LJ, Riou G, Pastan I, Gottesman MM, Bénard J. Expression of a human multidrug resistance gene in ovarian carcinomas. Cancer Res 1989;49:5062-5.

68. Holzmayer TA, Hilsenbeck S, Von Hoff DD, Roninson IB. Clinical correlates of MDR1 (P-glycoprotein) gene expression in ovarian and small-cell lung carcinomas. J Natl Cancer Inst 1992;84:1486-91.

69. Patch AM, Christie EL, Etemadmoghadam D, et al. Whole-genome characterization of chemoresistant ovarian cancer. Nature 2015;521:489-94.

70. Hlavac V, Brynychova V, Vaclavikova R, et al. The expression profile of ATP-binding cassette transporter genes in breast carcinoma. Pharmacogenomics 2013;14:515-29.

71. Arts HJ, Katsaros D, de Vries EG, et al. Drug resistance-associated markers P-glycoprotein, multidrug resistance-associated protein 1, multidrug resistance-associated protein 2, and lung resistance protein as prognostic factors in ovarian carcinoma. Clin Cancer Res 1999;5:2798-805.

72. Kamazawa S, Kigawa J, Kanamori Y, et al. Multidrug resistance gene-1 is a useful predictor of Paclitaxel-based chemotherapy for patients with ovarian cancer. Gynecol Oncol 2002;86:171-6. 
73. Ohishi Y, Oda Y, Uchiumi T, et al. ATP-binding cassette superfamily transporter gene expression in human primary ovarian carcinoma. Clin Cancer Res 2002;8:3767-75.

74. Obata H, Yahata T, Quan J, Sekine M, Tanaka K. Association between single nucleotide polymorphisms of drug resistance-associated genes and response to chemotherapy in advanced ovarian cancer. Anticancer Res 2006;26:2227-32.

75. Marsh S, Paul J, King CR, Gifford G, McLeod HL, Brown R, et al. Pharmacogenetic assessment of toxicity and outcome after platinum plus taxane chemotherapy in ovarian cancer: the Scottish Randomised Trial in Ovarian Cancer. J Clin Oncol 2007;25:4528-35.

76. Sparreboom A, Loos WJ, Burger H, et al. Effect of ABCG2 genotype on the oral bioavailability of topotecan. Cancer Biol Ther 2005;4:650-8.

77. Tian C, Ambrosone CB, Darcy KM, et al. Common variants in $\mathrm{ABCB} 1, \mathrm{ABCC} 2$ and $\mathrm{ABCG} 2$ genes and clinical outcomes among women with advanced stage ovarian cancer treated with platinum and taxane-based chemotherapy: a Gynecologic Oncology Group study. Gynecol Oncol 2012;124:575-81.

78. He QZ, Luo XZ, Wang K, et al. Isolation and characterization of cancer stem cells from high-grade serous ovarian carcinomas. Cell Physiol Biochem 2014;33:173-84.

79. Januchowski R, Sterzynska K, Zaorska K, et al. Analysis of MDR genes expression and cross-resistance in eight drug resistant ovarian cancer cell lines. J Ovarian Res 2016;9:65.

80. Maliepaard M, van Gastelen MA, de Jong LA, et al. Overexpression of the BCRP/MXR/ABCP gene in a topotecan-selected ovarian tumor cell line. Cancer Res 1999;59:4559-63.

81. Jia P, Wu S, Li F, et al. Breast cancer resistance protein-mediated topotecan resistance in ovarian cancer cells. Int J Gynecol Cancer $2005 ; 15: 1042-8$

82. Nicholls SJ, Ray KK, Johansson JO, et al. Selective BET Protein Inhibition with Apabetalone and Cardiovascular Events: A Pooled Analysis of Trials in Patients with Coronary Artery Disease. Am J Cardiovasc Drugs 2018;18:109-15.

83. Ray KK, Nicholls SJ, Buhr KA, et al. Effect of Apabetalone Added to Standard Therapy on Major Adverse Cardiovascular Events in Patients With Recent Acute Coronary Syndrome and Type 2 Diabetes: A Randomized Clinical Trial. JAMA 2020;323:1565-73.

84. Gilham D, Wasiak S, Tsujikawa LM, et al. RVX-208, a BET-inhibitor for treating atherosclerotic cardiovascular disease, raises ApoA-I/ HDL and represses pathways that contribute to cardiovascular disease. Atherosclerosis 2016;247:48-57.

85. Haarhaus M, Ray KK, Nicholls SJ, et al. Apabetalone lowers serum alkaline phosphatase and improves cardiovascular risk in patients with cardiovascular disease. Atherosclerosis 2019;290:59-65.

86. Jahagirdar R, Zhang H, Azhar S, et al. A novel BET bromodomain inhibitor, RVX-208, shows reduction of atherosclerosis in hyperlipidemic ApoE deficient mice. Atherosclerosis 2014;236:91-100.

87. Wasiak S, Tsujikawa LM, Halliday C, et al. Benefit of Apabetalone on Plasma Proteins in Renal Disease. Kidney Int Rep 2018;3:711-21. 